\title{
外部圧縮型超音速インテーク性能に及ぼすスリット抽気の影響*1 Influences of Slit Bleed on the Performances of an External-Compression Supersonic Air-Intake
}

\author{
西 澤 宇 一*2. 亀 田正 治*2 ·渡辺安*3 \\ Uichi Nishizawa, Masaharu Kameda and Yasushi Watanabe
}

\begin{abstract}
Key Words : Supersonic Air-Intake, Bleed, Shock Wave, Boundary Layer, Separation, Mass Flow Rate, Pressure Recovery
\end{abstract}

\begin{abstract}
The performance of a two-dimensional Mach 1.64 external compression air intake is investigated by computational fluid dynamics. The intake model consists of a 10-degree wedge and a subsonic diffuser. The flow in and around the intake with different configurations of the slit at the diffuser entrance is calculated to examine the effect of the configurations for pressure recovery and stability of the shock system. The numerical results indicate that the natural bleed fairly improves the intake performance at subcritical operation: It improves the maximum pressure recovery and the tolerance of the mass flow rate through the diffuser to guarantee the stability of the shock. The bleed mass flow rate strongly depends on the slit configuration. Large bleed mass flow rate increases the tolerance of the diffuser mass flow rate for the shock stability. However, the presence of the slit provides no gain in efficiency of the intake at supercritical operation.
\end{abstract}

\section{記号 の 説 明}

$$
\begin{aligned}
A & : \text { 面積 } \\
D_{\mathrm{s}} & : \text { スリット深さ } \\
D_{\mathrm{sc}} & : \text { スリットの中心線に沿ったスリット深さ } \\
h & : \text { 高さ } \\
l_{\mathrm{ir}} & : \text { インテーク長さ (ランプ側 }) \\
l_{\mathrm{r}} & : \text { ランプの長さ } \\
L & : \text { スリット出入口長さ } \\
M & : \text { マッハ数 } \\
\mathrm{MFR} & : \text { 質量流量 } \\
\mathrm{PR} & : \text { 圧力回復率 } \\
P_{\mathrm{t}} & : \text { 全圧 } \\
R e & : \text { レイノルズ数 } \\
s & : \text { インテーク中心線に沿った座標 } \\
u & : x \text { 方向の速度成分 } \\
U & : \text { 速度 } \\
x, y & : \text { 座標 } \\
\rho & : \text { 密度 } \\
\theta & : \text { 角度 } \\
\text { 添え字 } & \\
0 & : \text { 主流 } \\
\mathrm{c} & : \text { インテーク捕獲位置 } \\
\mathrm{e} & : \text { インテーク出口 }
\end{aligned}
$$

\footnotetext{
*1 (C) 2008 日本航空宇宙学会

平成 19 年 10 月 14 日原稿受理

$* 2$ 東京農工大学大学院工学府

*3 宇宙航空研究開発機構
}

$$
\begin{aligned}
& \mathrm{fp} ： \text { フロー・プラグ前面位置 } \\
& \text { si：スリット入口 } \\
& \text { so：スリット出口 } \\
& \text { th：スロート位置 }
\end{aligned}
$$

1. は じめ に

国際化の進展に伴い，次世代超音速輸送機 $\mathrm{SST}$ : Supersonic Transport) 開発の機運が再び高まっている. 国 内でも, 日仏超音速機共同研究や, サイレント超音速旅客 機（Silent SST）研究会等の活動が活発に行われている.

本研究では, SST 用エンジンの構成要素の一つである超 音速インテーク1)を取り上げる，超音速インテークは，エ ンジン用空気の取り込み，減速・圧縮過程を担う重要なデ バイスである。

超音速インテークは，超音速圧縮部と亜音速ダクト（ディ フューザ）から構成される。超音速圧縮部では，インテー ク先端に取り付けたランプ (ウェッジ，コーン）で発生す る斜め衝撃波と垂直衝撃波（ショックシステム）を利用し て空気の減速・圧縮が行われる。ランプ面上で発達する境 界層と衝撃波が干渉することで, 状況により流れのはく離 が誘発される，また，亜音速ディフューザにおいては，減 速による圧力回復，および，ショックシステムを通じて主 流から転向した流れを再転向させる必要から，流れのはく 離が誘起されやすい。これらの流れのはく離はインテーク 性能を著しく損なう要因となる1).

衝撃波/境界層干渉によって生じたはく離域がディフュー ザに流入することを防止し，かつ，ディフューザ自体によ る流れのはく離を抑制するためのデバイスとして，ランプ 
面での抽気 ${ }^{1,2)}$ がよく行われる. 実際のインテーク設計で は，抽気方法の最適化に細心の注意が払われている3 ${ }^{3,4)}$.

わが国でも，境界層抽気によるインテーク周り衝撃波/境 界層干渉の変化 ${ }^{5,6)}$, 亜音速ディフューザ性能の変化7)などの 研究が進められ，有益な知見が得られている。しかし，抽気 口を含むインテーク全機周りの流れを計算流体力学 $(\mathrm{CFD})$ により統合的に解析した例8) は少ない. 特に, 抽気口形状 の流れの様子を詳しく示した例は見当たらない.

本研究では, 外部圧縮型インテークを対象として CFD シミュレーションを行い，さまざまな作動状態に扔ける流 れ特性について，抽気の有無や抽気口の形状变化の影響を 詳しく調べた。その結果, 抽気によりインテーク性能が著 しく改善されることを確認した。また，抽気流量は抽気口 形状や作動状態の影響を強く受け，それに応じてインテー ク性能が大きく変わることを明らかにした。

$$
\text { 2. インテーク・モデル }
$$

主流マッハ数 $M=1.64$ を設計点とする完全外部圧縮 型 2 次元インテーク・モデルを計算対象とした。本モデル は，SST 用インテークを念頭に置いて設計されたものであ り, 並行して進めている風洞実験 ${ }^{9,10)}$ 用モデルと同一形状 である。

模式図を第 1 図に示す。前方の超音速圧縮部と後方の亜 音速ディフューザ部から構成される．前方部分のくさび形 状が超音速圧縮に用いるランプである。亜音速ディフュー ザを構成する壁面のうちランプ側と反対側の面をカウルと 呼ぶ．カウル・リップは鈍頭形状である．モデルの後方部 には，流量調節用のフロー・プラグが配置されている。 た，抽気用スリットは，ランプ後方の亜音速ディフューザ 入口に設けられている.

2.1 超音速圧縮部 ランプ先端の転向角は $10^{\circ}$, ランプ の長さは, 超音速インテークの捕獲高さ $h_{\mathrm{c}}$ を基準長さと して $l_{\mathrm{r}}=1.5 h_{\mathrm{c}}$ とした。 また，カウル・リップの曲率半径 は $0.025 h_{\mathrm{c}}$ とした。ランプ先端から発生する斜め衝撃波に より, 流入気体のマッ八数は $M=1.3$ になり, 続いて, カ ウル・リップ前方からランプ側スリット近傍に発生する垂 直衝撃波により $M=0.79$ になる。 これらのショックシス テムによる全圧回復率の理論值は約 0.98 である.

2.2 亜音速ディフューザ部 入口（スロート）高さ $h_{\mathrm{th}}$ $\left(=0.74 h_{\mathrm{c}}\right)$ を基準として亜音速ディフューザ部を設計し た（第 1 図 (b))。ディフューザ部の全長は $10 h_{\mathrm{th}}$ である。 ディフューザの前半部分は円弧状（曲率半径 $20 h_{\mathrm{th}}$ ）流路と し，ランプによって一様流に対して $10^{\circ}$ 転向された流れを $0^{\circ}$ まで戻した。この部分の長さは $3.5 h_{\mathrm{th}}$ である。また，こ の間のディフューザ断面積変化は, 等エントロピ流れを仮 定したときのマッ八数勾配 $\mathrm{d} M / \mathrm{d} s$ が一定值 $\left(-0.08 / h_{\mathrm{th}}\right)$ となるよう決定した。一方, 後半部分 (全長 $6.5 h_{\mathrm{th}}$ ) では, マッ八数勾配がなめらかに 0 へ近づくよう断面積を変化さ せた。フロー・プラグがない場合の出口高さ $h_{\mathrm{e}}$ は $1.23 h_{\mathrm{c}}$ である。

2.3 抽気用スリット カウル・リップ先端からランプ面

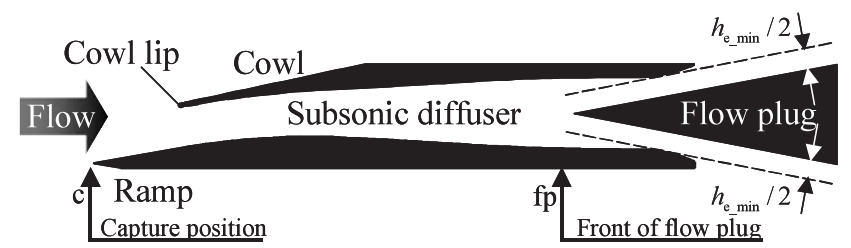

(a) 各部の名称

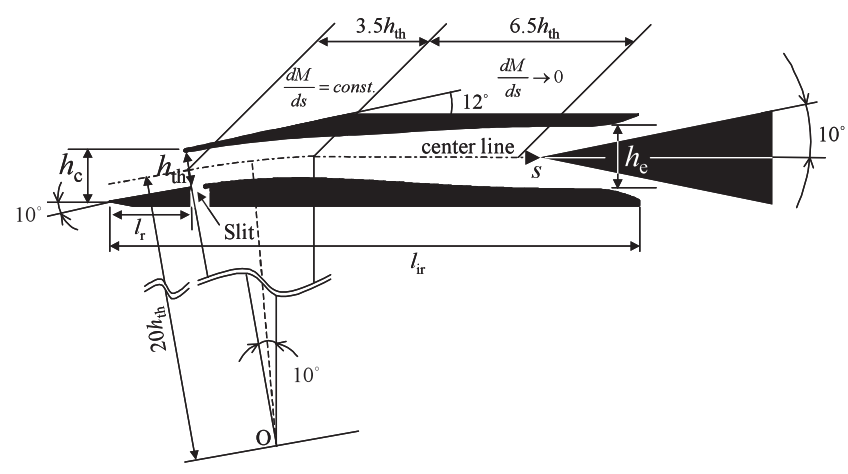

(b) 主な設計パラメータ

第 1 図 2 次元超音速インテーク・モデル

に下した垂線とランプ面との交点に，開口部先端が位置す るようスリットを設けた。スリットは風洞実験用の模型と 同一形状であり，詳細は 3.3 節にて述べる。

2.4 フロー・プラグ フロー・プラグ位置を前後に移動 させ，インテーク出口最小高さ $\left(h_{\mathrm{e} \_ \text {min }}\right)$ を変化させ, 流 量·背圧を調節した $h_{\mathrm{e} \_ \text {min }}$ に応じて, 第 2 図に示すような 亜臨界状態，臨界状態および超臨界状態の 3 種類の作動状 態を作り出すことができる．本モデルにおける臨界状態 (b) では, カウル・リップが鈍頭形状のため垂直衝撃波が亜音速 ディフューザ入口前面に扔いて離脱しており, 衝撃波の三 重点は捕獲高さの外側に存在する。臨界状態から, $h_{\mathrm{e} \_ \text {min }}$ を増す（フロー・プラグ位置を下げる）とディフューザ内 部に衝撃波が発生する超臨界状態 (a) となり, 逆に減少さ せると垂直衝撃波がランプ先端に近づく亜臨界状態 (c) と なる。

\section{3. 数值シミュレーション方法}

3.1 計算ソルバー 独立行政法人宇宙航空研究開発機 構 (JAXA) が開発した UPACS (Unified Platform for Aerospace Computational Simulation) ${ }^{11,12)}$ を使用して 非定常 2 次元数值シミュレーションを行った. 支配方程式 には圧縮性 full Navier-Stokes 方程式を用い，セル中心体 積法で離散化した。対流項の計算には Roe スキーム（空間 精度 3 次)，時間積分には陰解法を用いた. CFL 数を 2,000 として 50,000 ステップの計算を行った。また，乱流モデル は組み込まなかった。

3.2 計算格子 数值シミュレーションに使用した計算格 子を第 3 図に示す。格子生成を簡単化するため，領域を 5 ブ ロック（w/o slit）あるいは6ブロック（with slit）に分割し た. 代数型格子生成法で初期格子を生成し, 続いて楕円型偏 微分方程式による格子生成法を部分的に用いて格子形状を 


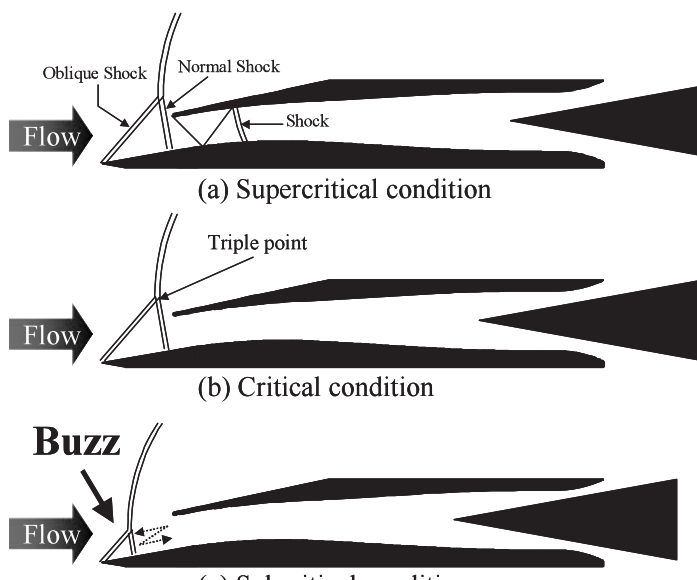

(c) Subcritical condition

第 2 図＼cjkstart超音速インテークの作動状態

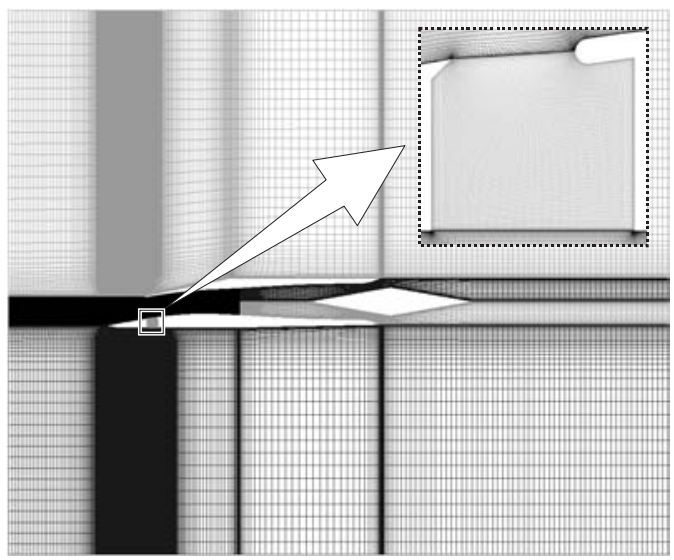

第 3 図計算格子

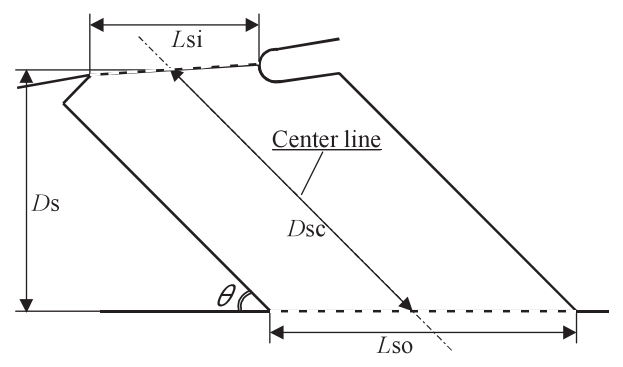

第 4 図抽気用スリットの形状

平滑化した. 2 次元平面に対する格子点総数は約 100,000 ～ 127,000 点である.スリット部の格子点数は約 13,000〜 22,000 点である. 最小格子幅は, 粘性底層内に数点入る

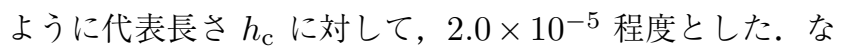
お，分割した格子は，マルチ・ブロック法により接続した。

3.3 計算条件と計算ケース 並行して進めている風洞実 験9, 10) に合わせて, 一様流マッ八数は 1.64 , よどみ点圧力 は $300 \mathrm{kPa}$ ，よどみ点温度は $400 \mathrm{~K}$ とした。主流のレイノ ルズ数 Re は, 捕獲高さ $h_{\mathrm{c}}$ を代表長さにすると約 $2.9 \times 10^{5}$ である。また，数值計算の開始条件は，インパルッシブ. スタートとした。

第 1 図 (a) に示すインテーク出口最小高さ $h_{\text {e_min }}$ をさま
第 1 表 抽気用スリット形状の值

\begin{tabular}{lccccc}
\hline Type & $L_{\mathrm{si}} / h_{\mathrm{c}}$ & $L_{\mathrm{so}} / h_{\mathrm{c}}$ & $D_{\mathrm{s}} / h_{\mathrm{c}}$ & $D_{\mathrm{sc}} / h_{\mathrm{c}}$ & $\theta[\mathrm{deg}]$ \\
\hline Wide & 0.240 & 0.394 & 0.344 & 0.346 & 90 \\
Wide+obli & 0.240 & 0.437 & 0.344 & 0.495 & 45 \\
Narrow & 0.240 & 0.295 & 0.344 & 0.345 & 90 \\
Narrow+obli & 0.240 & 0.295 & 0.344 & 0.501 & 45 \\
\hline
\end{tabular}

ざまに変えてインテーク性能の流量依存性を調べた． $h_{\mathrm{e} \_ \text {min }}$ はフロー・プラグとインテーク出口壁で作られる流路の最 小部であり, 約 $0.498 h_{\mathrm{c}}$ から約 $0.776 h_{\mathrm{c}}$ の間の 16 ケース について数值計算を行った。

スリットによる抽気方法は, 超音速インテーク内圧と外圧 を利用した自然抽気である。計算で用いたスリットの概略形 状を第 4 図に，形状パラメータの詳しい值を第 1 表に示す. 本計算では, 垂直で幅の広い wide タイプ, 傾斜角 45 [deg] で幅の広い wide+obli タイプ, 垂直で幅の狭い narrow 夕 イプおよび傾斜角 $45[\mathrm{deg}$ ] で幅の狭い narrow+obli タイプ の 4 種類のスリット形状とスリットなし（w/o slit）タイ プについて数值シミュレーションを行った。 入口側長さ $L_{\mathrm{si}}$ は一定とした。また，ランプ先端からスリット入口先端ま での距離 $l_{\mathrm{r}}$ も一定 (2.3 節) としたため, スリット深さ $D_{\mathrm{s}}$ も一定である。

\section{4. 数值シミュレーション結果および考察}

4.1 超音速インテークの作動状態 第 5 図には, スリッ トなしタイプと wide タイプに対するインテーク出口最小 高さによる質量流量の比較を示す. $\mathrm{MFR}_{\mathrm{fp}}$ は, 第 1 図 (a) に示した超音速インテーク前面位置での流入流量とフロー・ プラグ直前位置での流出流量との比であり, 式 (1) を用い て求めた。質量流量 $\mathrm{MFR}_{\mathrm{so}}$ は, 超音速インテーク前面位 置での流入流量とスリット出口での流出流量との比であり, 式 (2)を用いて求めた.

$$
\begin{aligned}
\operatorname{MFR}_{\mathrm{fp}} & =\frac{\rho_{\mathrm{fp}} U_{\mathrm{fp}} A_{\mathrm{fp}}}{\rho_{0} U_{0} A_{\mathrm{c}}} \\
\mathrm{MFR}_{\mathrm{so}} & =\frac{\rho_{\mathrm{so}} U_{\mathrm{so}} A_{\mathrm{so}}}{\rho_{0} U_{0} A_{\mathrm{c}}}
\end{aligned}
$$

ただし，断面積 $A_{\mathrm{c}}, A_{\mathrm{fp}}$ および $A_{\mathrm{so}}$ は，長さ $h_{\mathrm{c}}, h_{\mathrm{fp}}$ お よび $L_{\mathrm{so}}$ を代わりにそれぞれ用いた。

第 5 図では，インテークの流出流量 $\mathrm{MFR}_{\mathrm{fp}}$ の減少にと もなって，スリットを通る流量 $\mathrm{MFR}_{\mathrm{so}}$ が増加している様 子が捉えられている. $\mathrm{MFR}_{\mathrm{fp}}$ の減少域は亜臨界作動状態に 対応している．超臨界作動状態のとき，ディフューザ入口 の垂直衝撃波は形を変えず，スリット入口部の圧力も変化 しないので, $\mathrm{MFR}_{\mathrm{so}}$ は一定である。一方, 亜臨界作動状態 になるとディフューザ入口の垂直衝撃波は上流側へ徐々に 移動し, それに伴いスリット入口部の圧力も徐々に高まる. これによりスリット出口との圧力差が大きくなり, $\mathrm{MFR}_{\mathrm{so}}$ が増大する。

また，亜臨界作動状態におけるスリットのない場合と比心゙ ると，スリットを設けることで $h_{\mathrm{e} \_\mathrm{min}}$ は同じでも $\mathrm{MFR}_{\mathrm{fp}}$ が増加する。これは，スロート近傍に発生する垂直衝撃波 


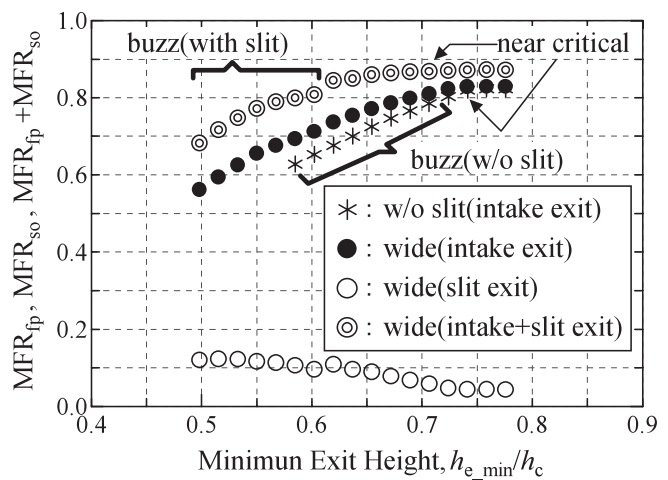

第 5 図 インテーク出口最小高さによる質量流量の変化

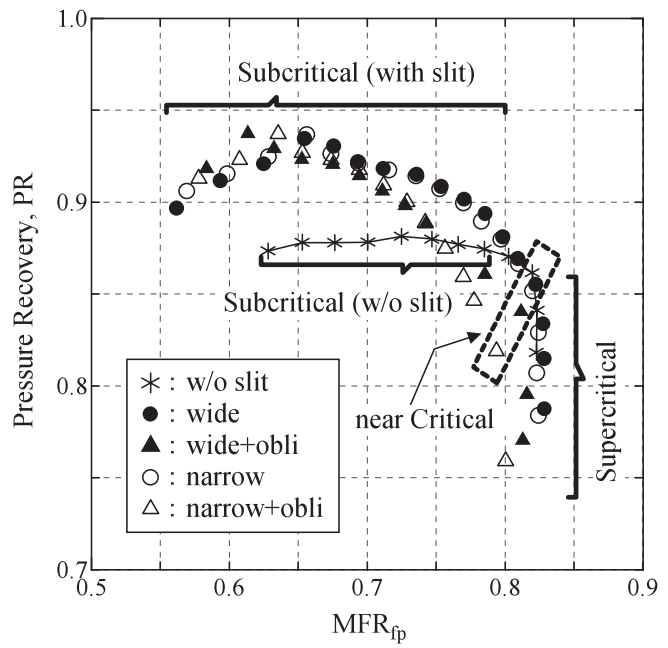

(a) 質量流量 $M_{F F}$ と圧力回復率 $\mathrm{PR}$ との関係

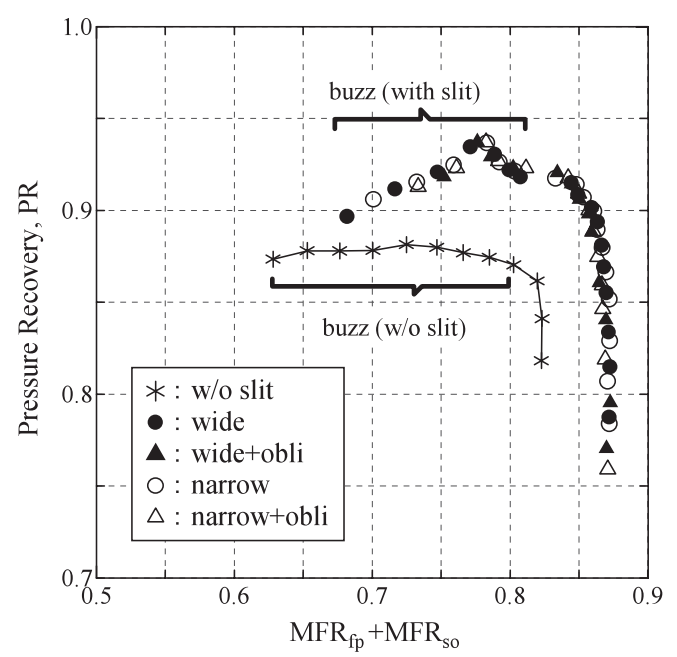

(b) 質量流量 $\mathrm{MFR}_{\mathrm{fp}}+\mathrm{MFR}_{\mathrm{so}}$ と圧力回復率 $\mathrm{PR}$ との関係

第 6 図＼cjkstart超音速インテークの作動状態

位置，および，亜音速ディフューザ内での流れのはく離の 違いが理由である。さらに詳しい説明は次節以降で行う。

第 6 図には, $\mathrm{MFR}_{\mathrm{fp}}$ および $\mathrm{MFR}_{\mathrm{fp}}+\mathrm{MFR}_{\mathrm{so}}$ と圧力回 復率 PR との関係を示す.PR は，フロー・プラグ先端の ディフューザ断面に扔ける全圧の平均值 $P_{\mathrm{tfp}}$ と主流全圧 $P_{\mathrm{t} 0}$ の比として定義した.

まず，亜臨界作動状態に着目する，圧力回復率の最大值
は，すべて亜臨界作動状態に扔いて得られる。しかし，そ の值はスリットなしでは $88 \%$ 程度に留まるが，スリットを 設けることで $94 \%$ 程度までタイプにかかわらず高まる。さ らに，スリットを設けることで，亜臨界作動状態における 衝撃波振動現象 (バズ) ${ }^{1)}$ の発生開始 $\mathrm{MFR}_{\mathrm{fp}}$ の值が大幅に 低下していることがわかった。また，バズ発生 $\mathrm{MFR}_{\mathrm{fp}}$ の 值はスリット形状によって異なる。 バズ発生開始 $\mathrm{MFR}_{\mathrm{fp}}$ の各值は, スリットなしで約 0.77 , 傾斜を設けない wide タイプで約 0.71, narrow タイプで約 0.69, 傾斜を設けた wide+obli タイプで約 0.65 , narrow+obli タイプで約 0.67 であった。しかし，スリット抽気量も加味した第 6 図 (b) に示す $\mathrm{MFR}_{\mathrm{fp}}+\mathrm{MFR}_{\mathrm{so}}$ の值からは，スリットありタイプ ではすべて 0.80 前後に発生開始点をもつことがわかる.

次に, 超臨界作動状態に着目する. 第 6 図 (a) の $\mathrm{MFR}_{\mathrm{fp}}$ をみると，傾斜のあるスリットでは，スリットなしや垂直 型スリットと比べて值が減少している。一方, 第 6 図 (b)に 示したスリットありタイプの $\mathrm{MFR}_{\mathrm{fp}}+\mathrm{MFR}_{\mathrm{so}}$ の值は, 約 0.87 とすべて同一であった.

以上をまとめると，スリットの設置により，(1）最大圧 力回復率の改善, (2) バズ開始 $\mathrm{MFR}_{\mathrm{fp}}$ の減少, (3) 超臨 界状態でのインテーク出口流量の低下，がみられた。それ ぞれの理由については次節以降で考察を行う。

4.2 インテークの流れ構造 第 7, 8 図には, インテーク 出口最小高さを超臨界作動状態に対して $h_{\text {e_min }} / h_{\mathrm{c}}=0.776$, 亜臨界作動状態に対しては第 6 図中に示す衝撃波振動現象 (バズ）がみられた $h_{\mathrm{e} \_ \text {min }} / h_{\mathrm{c}}=0.689$ (スリットなし), $h_{\text {e_min }} / h_{\mathrm{c}}=0.585$ (wide, narrow), $h_{\text {e_min }} / h_{\mathrm{c}}=0.550$ (wide+obli, narrow+obli) としたときの等マッハ数分布 を示す.

第 7 図の超臨界作動状態における垂直衝撃波とカウル． リップとの位置関係に着目すると, スリットを設けること で，衝撃波がカウル・リップに近づいていることが確認でき る.第 9 図に, スリットなし, wide, wide+obli タイプに おける超臨界作動状態での衝撃波の詳しい位置を示す。こ の図は, $M=1.64$ (oblique shock) と $M=1.0$ (normal shock）の線を抽出したものである。どちらのスリットあ りタイプでも，垂直衝撃波はカウル・リップおよび抽気用 スリットの入口に近づいている. さらに詳しくみると, 傾 斜を設けたスリットのほうが，よりスリット近傍まで衝撃 波が引き寄せられている。これらの傾向は narrow 抢よび narrow+obli 夕イプでも同様であった。

スリットの有無による衝撃波位置の違いは, インテーク 捕獲流量のうちカウル・リップ前面を通じて漏れる（スピ レージ）流量が変化することによるものである. スリットを 設けると, スピレージを減らすために, 垂直衝撃波がカウ ル・リップに近づく. 第 6 図 (b)より, スリットのある場合 の $\mathrm{MFR}_{\mathrm{fp}}$ と $\mathrm{MFR}_{\mathrm{so}}$ の和はスリットのない場合の $\mathrm{MFR}_{\mathrm{fp}}$ に比べて大きい，すなわち，スピレージ流量が小さくなっ ている.

次に，亜音速ディフューザ内の流れのはく離に着目する。 まず，第 7 図の超臨界作動状態では，スリットの有無，形 


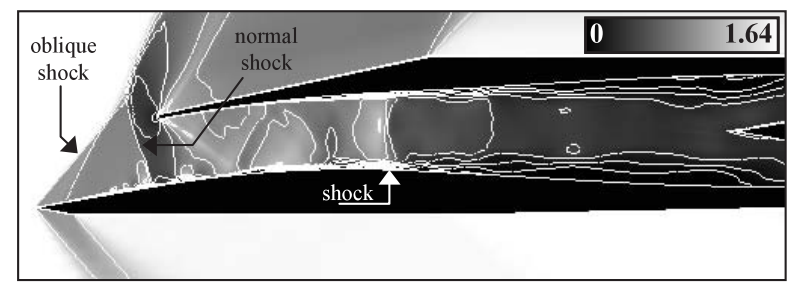

(a) スリットなしタイプ $\left(h_{\mathrm{e} \_ \text {min }} / h_{\mathrm{c}}=0.776\right)$

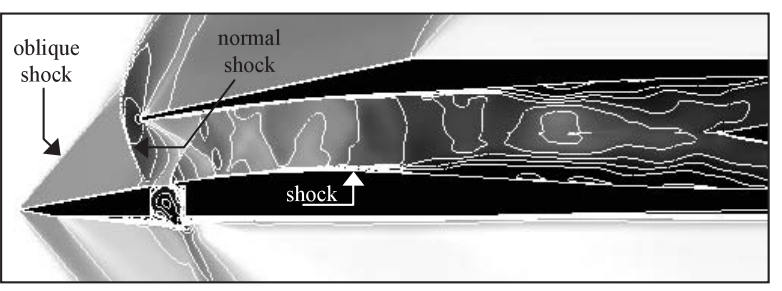

(b) wide タイプ $\left(h_{\mathrm{e} \_\min } / h_{\mathrm{c}}=0.776\right)$

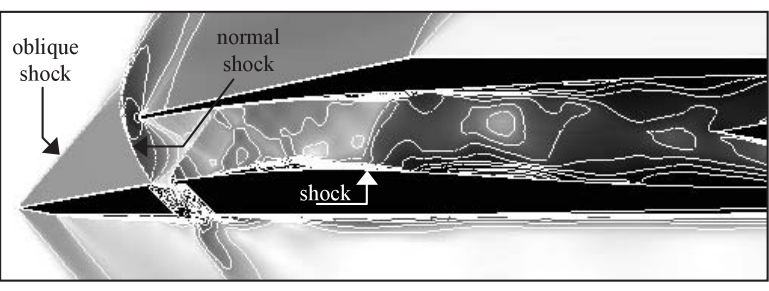

(c) wide+obli タイプ $\left(h_{\mathrm{e} \_\mathrm{min}} / h_{\mathrm{c}}=0.776\right)$

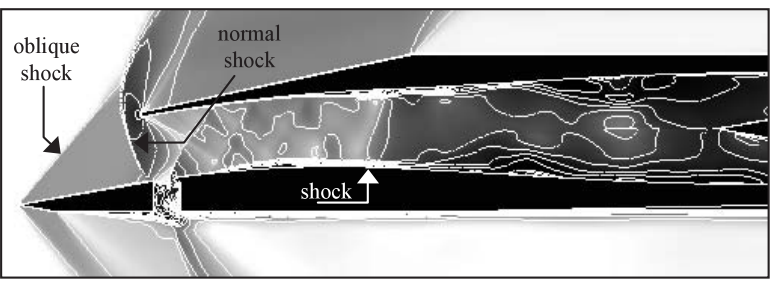

(d) narrow タイプ $\left(h_{\mathrm{e} \_ \text {min }} / h_{\mathrm{c}}=0.776\right)$

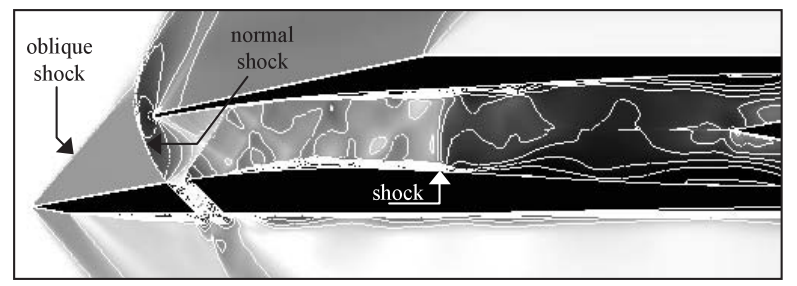

(e) narrow+obli タイプ $\left(h_{\mathrm{e} \_ \text {min }} / h_{\mathrm{c}}=0.776\right)$

第 7 図 等マッ八数分布（超臨界作動状態）

状によらず，亜音速ディフューザ内の最終衝撃波付近から の大規模な流れのはく離がカウル側，ランプ側両面にて確 認できる。また，この最終衝撃波位置は激しく非定常に振 動している.

次に，第 8 図に示す亜臨界作動状態では，スリットの有 無によりはく離の様子が異なる.スリットなしタイプでは, ランプ側にはランプ面上で発生した流れのはく離が亜音速 ディフューザ内に流入する様子がみられる。一方, カウル 側の流れのはく離は規模が小さい。これに対して，スリッ トありタイプでは，ランプ側におけるスリット下流での大 規模な流れのはく離は抑制される。しかし，カウル・リップ 付近を起点として発生している規模の大きなはく離が, 亜 音速ディフューザ内に存在する。

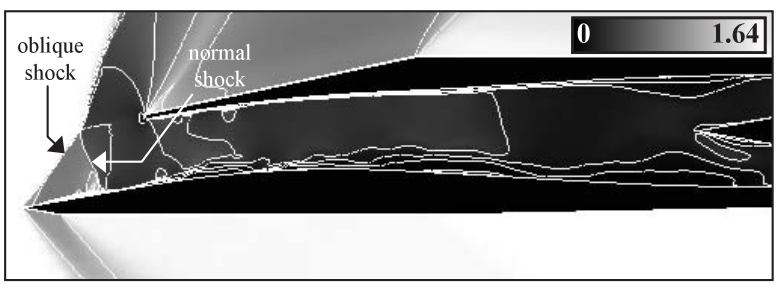

(a) スリットなしタイプ $\left(h_{\mathrm{e} \_ \text {min }} / h_{\mathrm{c}}=0.689\right)$

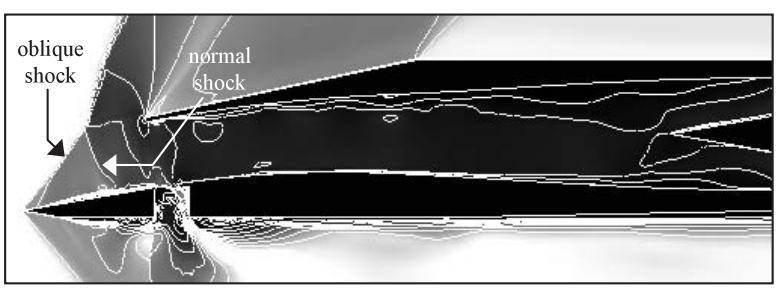

(b) wide タイプ $\left(h_{\mathrm{e} \_\min } / h_{\mathrm{c}}=0.585\right)$

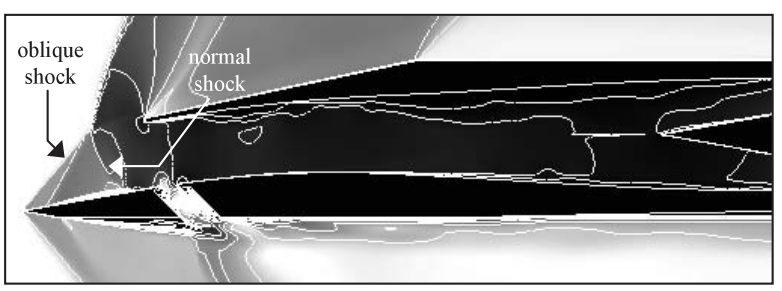

(c) wide+obli タイプ $\left(h_{\mathrm{e} \_ \text {min }} / h_{\mathrm{c}}=0.550\right)$

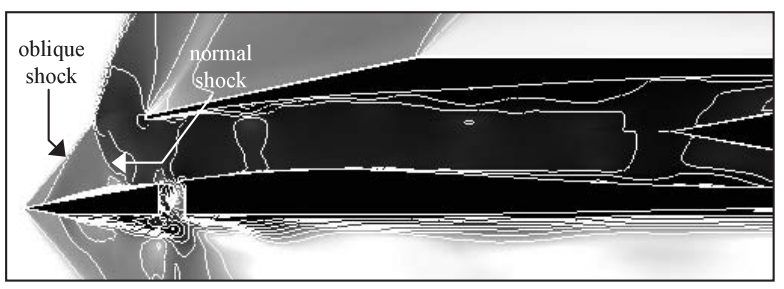

(d) narrow タイプ $\left(h_{\mathrm{e} \_ \text {min }} / h_{\mathrm{c}}=0.585\right)$

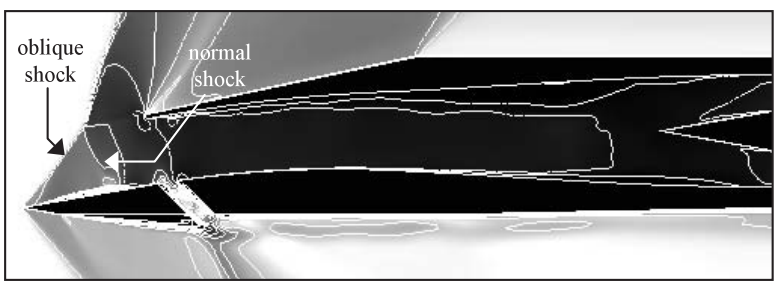

(e) narrow+obli タイプ $\left(h_{\mathrm{e} \_ \text {min }} / h_{\mathrm{c}}=0.550\right)$ 第 8 図 等マッ八数分布 (亜臨界作動状態)

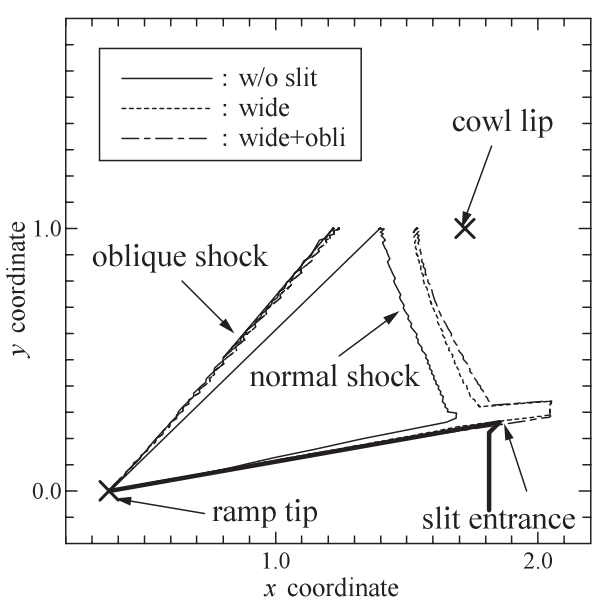

第 9 図 各タイプにおける衝撃波の位置（超臨界作動状態： $\left.h_{\mathrm{e} \_\min } / h_{\mathrm{c}}=0.776\right)$ 


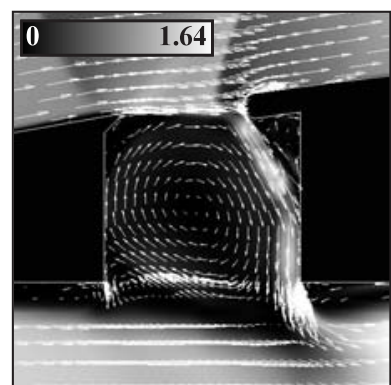

(a) wide タイプ

$\left(h_{\mathrm{e} \_ \text {min }} / h_{\mathrm{c}}=0.776\right)$

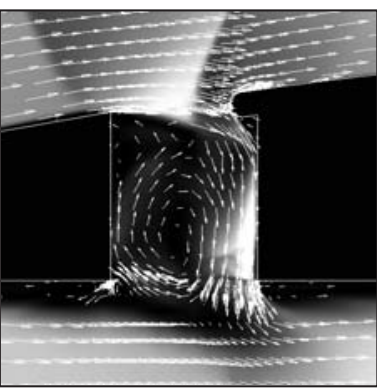

(c) narrow タイプ

$\left(h_{\mathrm{e} \_ \text {min }} / h_{\mathrm{c}}=0.776\right)$

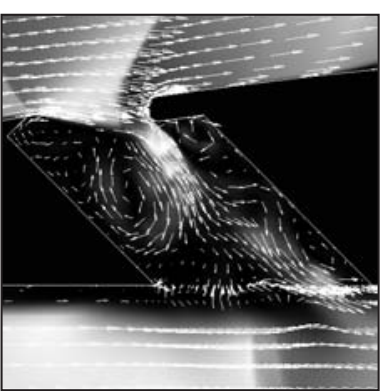

(b) wide+obli タイプ $\left(h_{\mathrm{e} \_ \text {min }} / h_{\mathrm{c}}=0.776\right)$

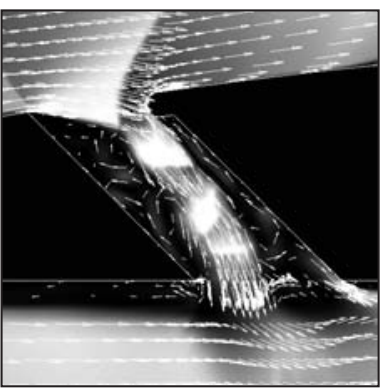

(d) narrow+obli タイプ $\left(h_{\mathrm{e} \_ \text {min }} / h_{\mathrm{c}}=0.776\right)$
第 10 図 抽気用スリットでの等マッ八線図と速度ベクトル（超臨界 作動状態)

スリットを設けることでランプ面上に生じたはく離域が 排除された結果，ランプ側のはく離は抑えられたと考えら れる。一方, 超臨界作動状態と比較して亜臨界作動状態で カウル・リップ付近からのはく離が生じ易くなった原因は, 亜音速ディフューザ内衝撃波の消滅によるものである。ま た，巠臨界作動状態でスリットがある場合にカウル・リッ プ付近から大規模なはく離が生じた原因は，ディフューザ 入口の流れ方向がスリット流れの影響によりランプ側に引 き寄せられ（下向きになり），カウル・リップ近傍の流れが 低速，かつ流れ方向の逆圧力勾配が増大したためである.

4.3 抽気用スリットの状態 第 10, 11 図には, 超臨界 作動状態と亜臨界作動状態の各スリット・タイプに対して スリット部を拡大した等マッハ数分布とベクトル線図を示 す。第 12 図には, 抽気用スリット出口での流出流量を示 す。抽気用スリット出口での流出流量は，式 (2)により整 理した。

はじめに，超臨界作動状態に着目する。まず，wide 夕イ プ（第 10 図 (a)）では, 非常に安定した大きな渦が存在し, 渦の横の狭い領域に流入側から流出側への流路が形成され ている。抽気用スリット出口での流出流量比 $\mathrm{MFR}_{\mathrm{so}}$ は約 $4.3 \%$ であ。次に, wide+obli タイプ（第 10 図 (b)）では 安定した渦は形成されず, 複雑な流動を示す流路が存在し ている. $\mathrm{MFR}_{\mathrm{so}}$ は傾斜のないタイプに比べて大きく, 約 $5.7 \%$ であ。一方, narrow夕イプ(第10図 (c)) ではwide タイプと同様に大きな渦が存在するが, 時々刻々と渦の形 状を変化させている． $\mathrm{MFR}_{\mathrm{so}}$ は約 $4.8 \%$ である。さらに， narrow+obli タイプ (第 10 図 (d)) では, wide+obli タイ

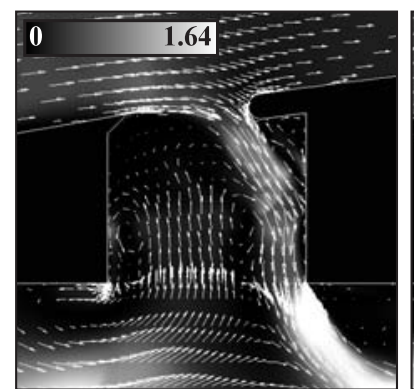

(a) wide タイプ

$\left(h_{\mathrm{e} \_ \text {min }} / h_{\mathrm{c}}=0.585\right)$

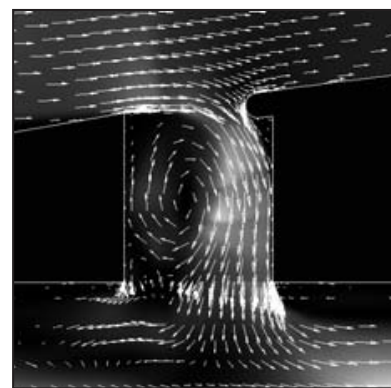

(c) narrow タイプ

$\left(h_{\mathrm{e} \_ \text {min }} / h_{\mathrm{c}}=0.585\right)$

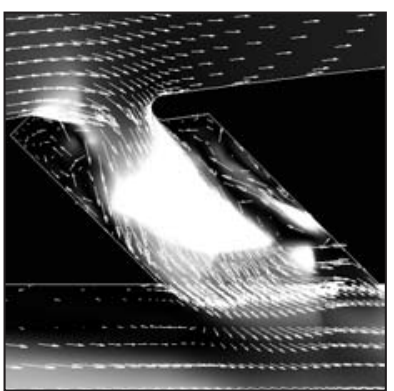

(b) wide+obli タイプ $\left(h_{\mathrm{e} \_ \text {min }} / h_{\mathrm{c}}=0.550\right)$

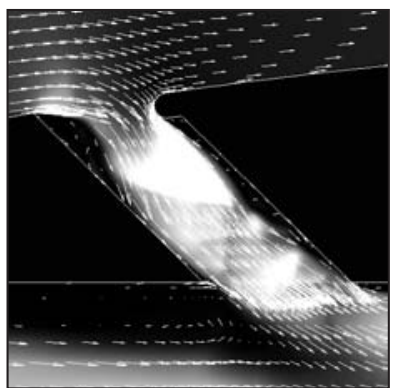

(d) narrow+obli タイプ $\left(h_{\mathrm{e} \_\min } / h_{\mathrm{c}}=0.550\right)$
第11図 抽気用スリットでの等マッハ線図と速度ベクトル（亜臨界 作動状態)

プと同様に複雑な流動を示す流路が存在している. $\mathrm{MFR}_{\mathrm{so}}$ は約 $7.0 \%$ であ。

以上より，傾斜を設けることで $\mathrm{MFR}_{\mathrm{so}}$ の值が 3 割から 5 割程度大きくなることがわかる。これに対して，第 9 図 に示すとおり，ディフューザ入口の衝撃波形状はほとんど 差がみられないため, スピレージを差し引いたインテーク への流入流量はほぼ一定である（第 6 図 (b)). その結果, 第 6 図 (a) の超臨界作動状態における傾斜のあるスリット の $\mathrm{MFR}_{\mathrm{fp}}$ の值は, それ以外のものに比べて小さくなった といえる。

さらに, 超臨界作動状態では, インテーク出口最小高さ によらず $\mathrm{MFR}_{\mathrm{so}}$ の值は一定となった.これも, ディフュー ザ入口垂直衝撃波の位置がほぼ等しいためである。第 7 図 に示すとおり，スロート近傍の垂直衝撃波が前方に押し出 されはじめる（臨界作動状態）まで，衝撃波はスリットの ごく直前に形成される。スリット入口における流れの条件 は衝撃波背後の状態に依存し, 衝撃波の位置がほぼ等しい ときは一定となる。その結果, スリット流量もまた一定と なる。

次に，亜臨界作動状態に着目する。まず，wide タイプ （第 11 図 (a)）では, 超臨界作動状態のときにみられた安 定した大きな渦は存在せず，非常に複雑な流動を示してい る。流路の幅が広がり, $\mathrm{MFR}_{\mathrm{so}}$ は最大約 $12.3 \%$ に増加し ている. 次に, wide+obli タイプ（第 11 図 (b)) では，ス リット形状に沿った幅の広い流路が比較的安定して形成さ れている. $\mathrm{MFR}_{\mathrm{so}}$ は約 $16.9 \%$ ，傾斜を設けない場合に 比べて非常に大きくなる。一方, narrow タイプ（第 11 図 


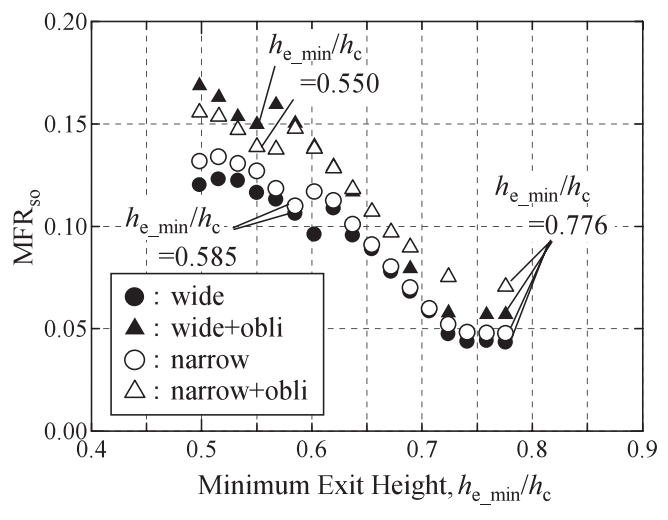

第 12 図抽気用スリット出口での流出流量

(c)）では, 超臨界作動状態時と同様に時々刻々と形状を変 化させる渦が存在する． $\mathrm{MFR}_{\mathrm{so}}$ は約 $13.4 \%$ であ。最後 に narrow+obli タイプ（第11 図 (d)）では, スリット形状 に沿った幅の広い流路が安定して形成されている. $\mathrm{MFR}_{\mathrm{so}}$ は約 $15.6 \%$ ある。

以上より，抽気用スリット周りの流れは，スリット形状 および作動状態への依存が大変強いことがわかる，実際の インテーク設計では, 例えば, アスペクト比 $L / D$ (本論文 では $\left.L_{\mathrm{so}} / D_{\mathrm{s}}\right)$ が 1 前後になると大きな渦がスリット内に 存在し，幅を拡大したにもかかわらずかえって流量が減少 することや，傾斜の有無により流量が $30 \%$ 以上変化するこ となどに注意を払う必要がある。

4.4 ランプ面上でのはく離位置とバズの発生状態 第 13 図には，ランプ面上での $x$ 方向のはく離開始点の平均, 上流抒よび下流位置を，スリットなしタイプと各スリット． タイプについてそれぞれ示す。はく離開始点は，ランプ壁 面近傍での $x$ 方向の速度成分 $u$ が $\mathrm{d} u / \mathrm{d} y=0$ となる位置 とした。

超臨界作動状態でのはく離点の平均位置は, スリットあ りタイプではどれも下流側のスリット入口近くにある。一 方，スリットなしタイプのはく離点の平均位置は，ランプ 先端一スリット入口間のランプ先端から約 $1 / 3$ 下流側にあ る.これは, 第 9 図で示した衝撃波位置の違いと対応して いるものと考えられる.

亜臨界作動状態では, どのタイプでもランプ面上のはく 離点の平均位置は上流側へ徐々に移動し, 最終的にはラン プ先端近くに到達する。また，図を詳しくみると，スリッ トの有無によらず，はく離点の平均位置が $x / h_{\mathrm{c}}=0.6$ 前 後にいたると, はく離点の振幅が大きくなっている. 各ス リット・タイプに対するバズの発生流量比は第 6 図に示し たとおりであり, はく離点が $x / h_{\mathrm{c}}=0.6$ の位置に達する $\mathrm{MFR}_{\mathrm{fp}}+\mathrm{MFR}_{\mathrm{so}}$ の值（約 0.80）に対応していることがわ かる.

$x / h_{\mathrm{c}}=0.6$ という点は, 衝撃波の三重点から生じるせん 断層がカウル・リップと干渉しはじめる状態に相当してい る. スリットへの抽気流量 $\mathrm{MFR}_{\mathrm{so}}$ が付加されると, 同じ $\mathrm{MFR}_{\mathrm{fp}}$ でもスピレージが減少，すなわち，衝撃波位置がラ ンプ後方に引き寄せられるため，也ん断層とカウル・リッ

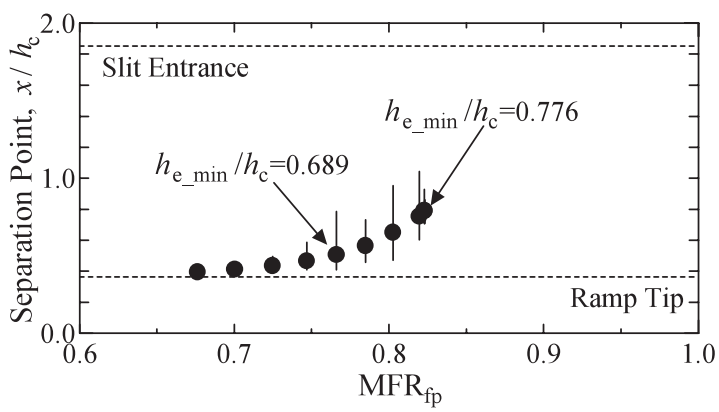

(a) w/o slit タイプ

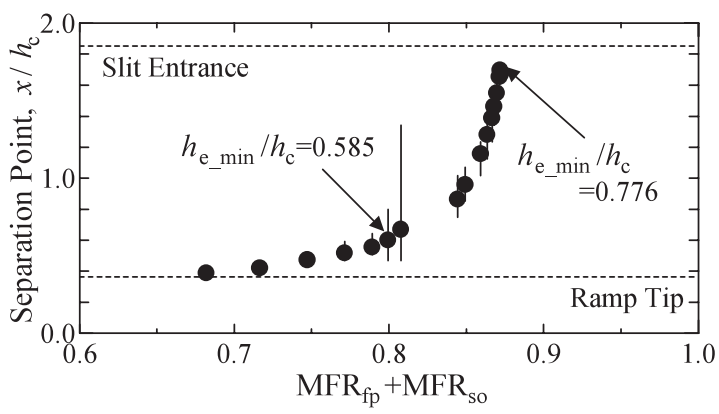

(b) wide タイプ

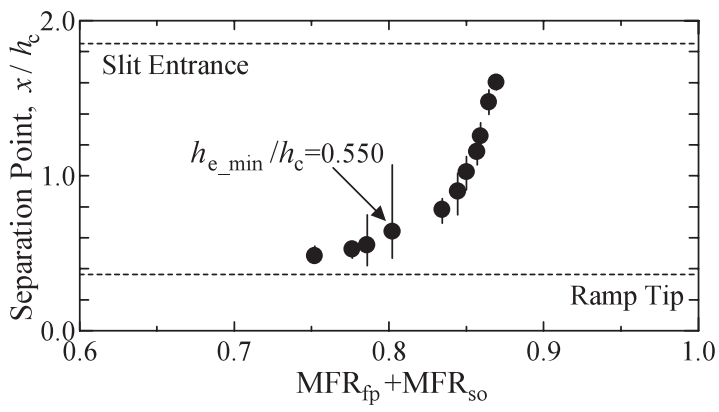

(c) wide+obli タイプ

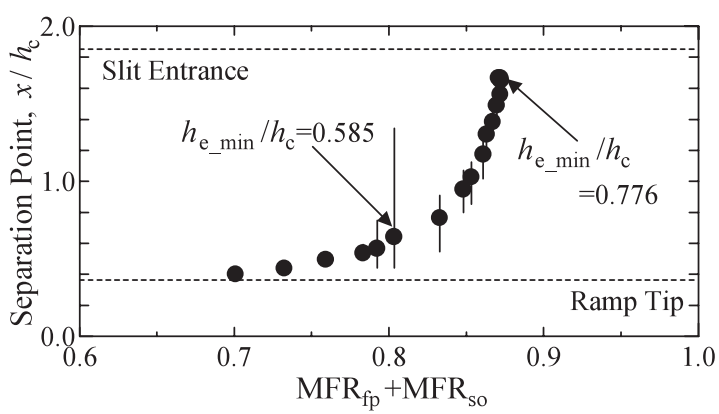

(d) narrow タイプ

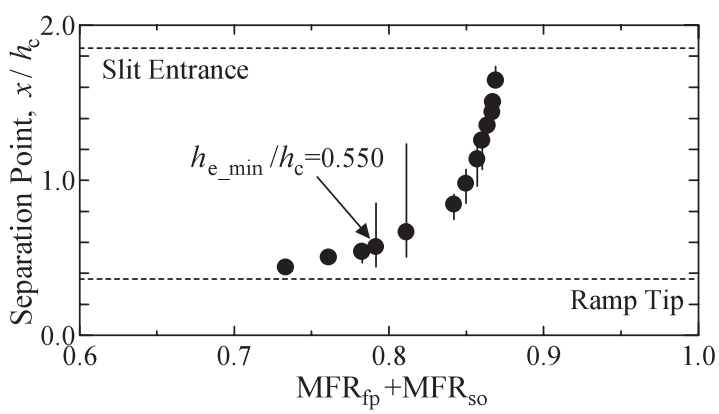

(e) narrow+obli タイプ

第 13 図 ランプ面上でのはく離の $x$ 方向変位 


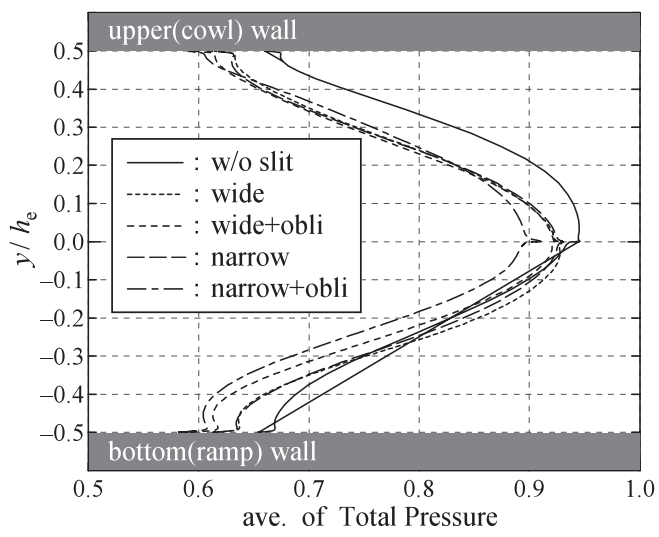

(a) 超臨界作動状態

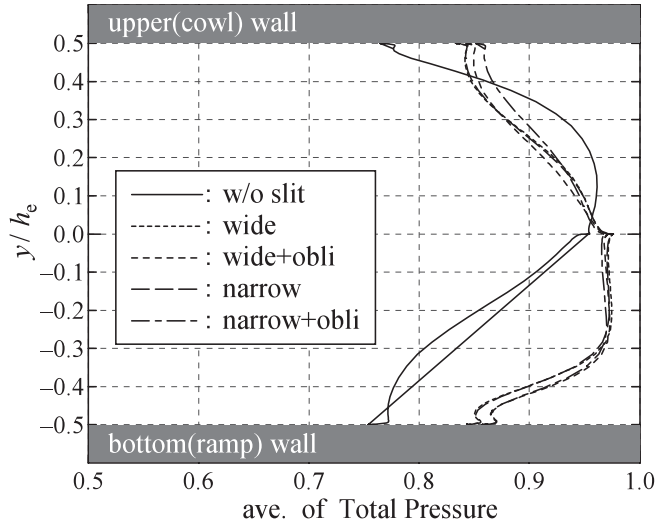

(b) 亜臨界作動状態

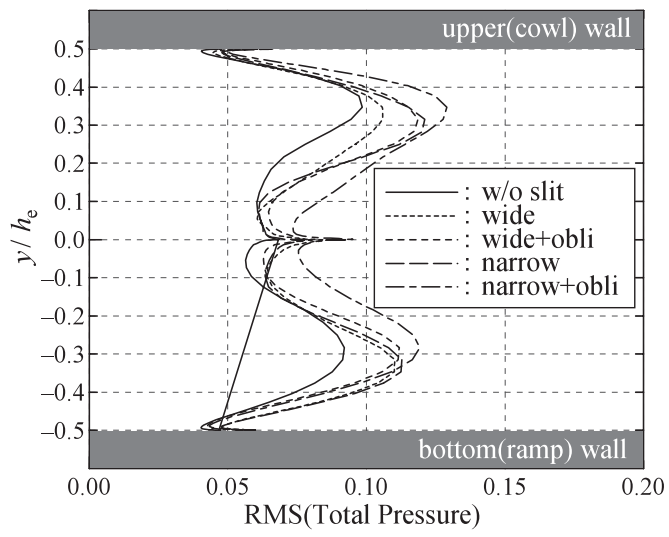

(a) 超臨界作動状態

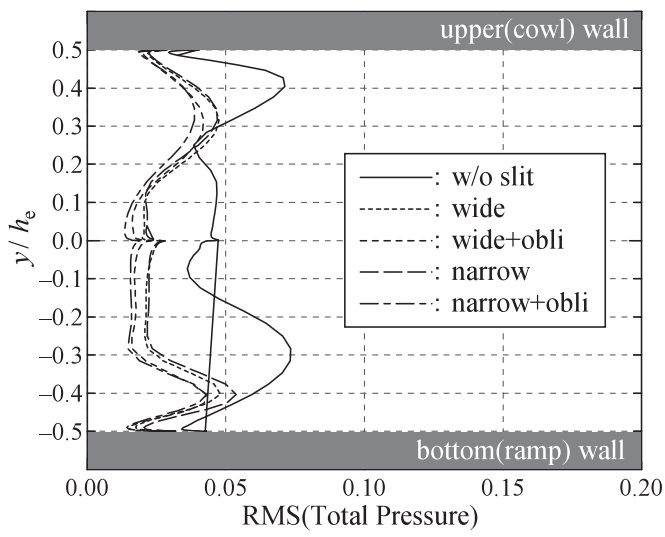

(b) 亜臨界作動状態
第 14 図 インテーク出口断面での全圧分布（座標ごとの時間平均）

プとの干渉が抑制される。その結果，亜臨界作動状態の幅 広い $\mathrm{MFR}_{\mathrm{fp}}$ においてバズの発生を抑えられる.

4.5 インテーク出口での圧力分布 第 14 図には，イン テーク出口断面に扔いて時間平均した全圧分布を示す. 計 算条件は第 7 図および第 8 図に相当する。それぞれの值は 主流の全圧で無次元化した。超臨界作動状態での全圧分布 は放物線型の上下対称である。一方，巠臨界作動状態での 全圧分布は上下非対称の台形型である。スリットなしでは カウル側で高い值を示し, スリットありでは形状に依存せ ずランプ側で高い值を示す.

これらの圧力分布の特徵は，はく離域の違いによるもの である。第 7 図に扔ける超臨界作動状態では，スリットの 有無に関倸なくはく離がカウル側とランプ側の両側に存在 する。これに対して，第８図（a）におけるスリットなし夕 イプでは, ランプ側のはく離がインテーク出口に存在して いる.

一方，第 8 図 (b)〜 (e) に扔けるスリットありタイプでは, すべてのタイプでカウル側からのはく離がインテーク出口 にまで達している。しかし，スリットを設けることで得ら れるランプ側の高い圧力回復により，カウル側のはく離に よる全圧低下を考慮に入れても, 全圧回復率の断面平均值 （第 6 図）は大きくなる.

第 15 図には，第 14 図で示した座標ごとの全圧（主流の 全圧で無次元化）に対する RMS 值の分布を示す. 超臨界
第 15 図 インテーク出口断面での全圧の RMS 值（座標ごと）

作動状態において，スリットありタイプはスリットなしタ イプよりも全圧の変動が大きくなっている。一方, 亜臨界 作動状態に拀いて，スリットありタイプはスリットなし夕 イプよりも全圧の変動が小さくなっている．また，超臨界 作動状態は, スリットの有無, 形状の違いによらず, 亜臨 界作動状態に比べて全圧の変動が大きい.

以上のことから，ディフューザ入口でのスリット抽気は， 亜臨界作動状態に㧍けるインテーク性能改善に大きな効果 をもつのに対し, 超臨界作動状態の性能改善にはつながら ないことがわかる.

なお，作動状態にかかわらずピークが二つみられるが，こ れらのピークは，フロー・プラグにより上下方向に流路が 分断されるために生じたものではなく, 亜音速ディフュー ザ部の衝撃波背後に存在する上下二つの流れのはく離域を 起因とする変動によるものである。第 16 図にフロー・プ ラグを使用せずに出口面積を調節した計算結果を示す。計 算で与えた流路形状を第 16 図 (a)に示す.スリットありの wide タイプにおける超臨界作動状態と亜臨界作動状態を比 較した。第 16 図 (b)の比較より, フロー・プラグの有無に かかわらず二つのピークが現れることがわかる.

\section{5. ま と め}

非定常 2 次元数值シミュレーションにより超音速インテー ク周りの流れ場を調べた。特に，抽気用スリットの有無お 


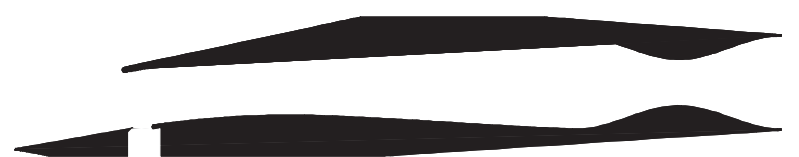

(a) フロー・プラグがない場合のインテーク形状

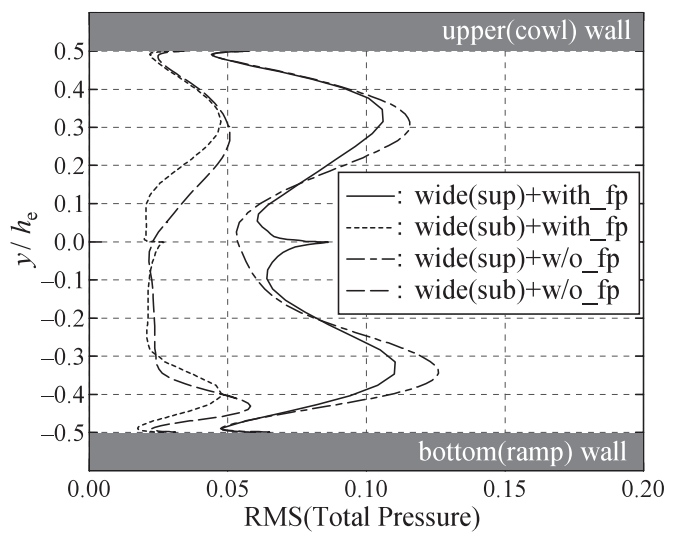

(b) インテーク出口断面での全圧の RMS 值（座標ごと）

第16図 フロー・プラグの有無によるインテーク出口 RMS 值の比較

よび形状変化による超音速インテーク性能の相違について 詳しく調べた。得られた主な結論は以下のとおりである.

1）スリット抽気により，亜臨界作動時にみられる圧力 回復率の最大值が増す。これは, スリットを付加すること で，ランプ側ディフューザ壁面のはく離が抑制されるため である。

2）スリット流量は形状に大変強く依存する。例えば，主 流方向に傾斜させたタイプのほうが, 主流と垂直なタイプ に比べて流量が大きい。

3）抽気用スリット出口での平均流出流量は, 超臨界状態 でほぼ一定であるが，亜臨界状態では急激に増加する。こ れは，ディフューザ入口垂直衝撃波の位置変化に対応して いる。
4）スリットを設けることで，亜臨界作動状態における バズの発生が抑制される。安定動作する $\mathrm{MFR}_{\mathrm{fp}}$ の領域は, スリット流量の増大にともない拡大する。

5）ディフューザ入口に抒けるスリット抽気は，超臨界作 動状態での圧力回復率や全圧変動の改善にはつながらない.

\section{参 考 文 献}

1) Seddon, J. and Goldsmith, E. L.: Intake Aerodynamics, 2nd ed., Blackwell Science, London, 1999.

2) 本阿弥眞治：圧縮性乱流せん断層の制御，日本機械学会論文集 B 編, 63 (1997), pp. 9-15.

3) Hamed, A. and Shang, J. S.: Survey and Assessment of Validation Data Base for Shockwave Boundary Layer Interactions in Supersonic Inlets, AIAA Paper 89-2939, 1989.

4) Harloff, G. J. and Smith, G. E.: Supersonic-Inlet BoundaryLayer Bleed Flow, AIAA J., 34 (1996), pp. 778-785.

5）小宮山文男，田中靖幸，志沢高朗，本阿弥眞治，坂田公夫，柳 良二, 進藤重美，村上 哲，吉永 崇，白石和雄，田中厚成：斜 め衝撃波と境界層の三次元干渉場に及ぼす抽気の影響, 日本機械 学会論文集 B 編，60 (1994), pp. 3408-3414.

6) 檀原伸補, 山本 誠, 本阿弥眞治, 坂田公夫：抽気を伴う斜め衝 撃波/乱流境界層の干渉場の三次元数值計算, 日本機械学会論文 集 B 編， 64 (1998), pp. 2417-2423.

7）坂本和之, 本阿弥眞治, 坂田公夫，村上 哲，進藤重美：入口衝 撃波を伴う亜音速ディフューザの流路形状に関する実験的研究, 日本機械学会論文集 B 編， 60 (1994), pp. 2261-2266.

8) 渡辺 安, 村上 哲, 藤原仁志: 超音速インテークの空力性能 に及ぼす側壁形状の影響, 宇宙航空研究開発機構研究開発報告, JAXA-RR-03-009, 2004.

9）西澤宇一，山本 伸，亀田正治：超音速インテーク周りの流れに 扔ける衝撃波の挙動, 日本航空宇宙学会第 36 期年会講演会講演 集, 2005, pp. $122-125$.

10）武田俊介, 西澤宇一, 亀田正治: 超音速インテークに㧍ける衝撃 波振動現象，日本機械学会 2006 年度年次大会，No. 2334, 2006.

11）山本一臣，高木亮治，山根 敬，榎本俊治，山崎裕之，牧田光正， 岩宮敏幸：CFD 共通基盤プログラム UPACS の開発，第 14 回 数值流体力学シンポジウム講演論文集, No. D02-1, 2000.

12) 山根 敬, 山本一臣, 榎本俊治, 高木亮治, 山崎光正, 山本 武, 岩宮敏幸, 中村 孝：CFD コード共通化プロジェクト UPACS の現状，航技研特別資料，SP-46, 2000, pp. 45-50. 